\title{
RESEARCH PAPER \\ COPING WITH LIFE IN A SQUATTER SETTLEMENT: THE CASE OF MIGRANT WOMEN IN KUMASI, GHANA
}

\author{
J. K. Owusu-Ansah ${ }^{1}$ and M. Addai $^{2}$ \\ ${ }^{1}$ Dept of Planning, KNUST, Kumasi \\ koansah@msn.com \\ ${ }^{2}$ Ablin Consult, Accra \\ natimash@yahoo.com
}

\begin{abstract}
With inner city migrant enclaves in Kumasi bursting at their seams and unable to accommodate the unending streams of in-migrants, a large-scale squatter settlement emerged on a disused Race Course to provide alternative shelter and quickly developed income generating opportunities. Its recent development, and the predominance of single-unattached women who were in the past seen as passive movers, provides a special research opportunity. Based on a sample of 100 female respondents, the research found that this overcrowded, unprotected, insecure and unsanitary environment was particularly challenging for the women as they coped with issues associated with their unique needs for shelter, safety and security. Contrary to popular perception, the settlement accommodated not only long-distance migrants but also Asantes who traditionally consider Kumasi as their home territory and were therefore expected to have been accommodated by a network of family members in indigenous Asante suburbs. Efforts to reduce their vulnerabilities will involve addressing their special needs through the delivery of affordable rental units and commercial space.
\end{abstract}

Keywords: migrant women, coping mechanisms, squatter settlement

\section{INTRODUCTION}

Women have conventionally been perceived as passive movers and therefore considered peripheral in the analyses of city-ward migration. In particular, the movements of married women were conditioned by that of their husbands (Cooke and Bailey, 1996). With respect to international migration, their legal statuses are sometimes conditioned by that of their husbands. This focus on the so-called 'trailing wife effect' essentially ignores other intricate independent migratory movements among women. Research has shown that some women actually take the lead and are later joined by their husbands (Whiteford, 1978; Pittin, 1984; Khoo et al., 1984; Fan and Huang, 1998). Others arrive unattached and unaccompanied in order to expand their educational and economic opportunities and/or to escape their disadvantaged positions particularly in male dominated cultures. 
Like their male counterparts, many secure a foothold in the city in informal settlements which are generally characterized by spatial disorganization, congestion, high crime rates, lack of essential services and more significantly the lack of personal social space resulting in gender violence and discrimination (UN HABITAT, 2003). The question then is how are these women, who have unique needs for shelter, privacy and security and potentially susceptible to gender-based violence, able to cope in such precarious environments and yet secure a foothold in the city? Existing research on migrant women in Ghana have focused on activities of female head porters (Oberhauser and Yeboah, 2011; Van den Berg, 2007; Baah-Ennumh et al., 2012) much to the neglect of other women in the migratory stream. This work adds a spatial dimension to the existing body of research by showing that, a cluster of migrants have, for the first time in the city's history, occupied a large tract of customary land illegally for their housing and income needs. The study analyses their motivations and their adaptive capacities in meeting their basic needs in such a precarious environment.

\section{Understanding rural-urban migration among women}

Migration is generally stimulated by structural, cultural, political and environmental factors which create socio-economic and spatial disparities. For many potential migrants, the decision to relocate is taken with much circumspection as they weigh the loss of their social network and local assets (ties to traditional homes and ancestral lands) against the potential opportunities in their desired destinations. Advanced information on potential destinations is gleaned through the display of "wealth" and urban lifestyles by returned migrants, through the glamour on urban-based television screens and through direct visits to a network of families and friends in the city (Cadwell, 1968; Okpara, 1998; Sluzki, 1993; Whiteford, 1978). For others, the decision to migrate is triggered by social conflicts and political instability, cultural conservatism, environmental degradation (linked to climate change and population pressure) and indebtedness to local barons (Hear et al., 2012; Pittin, 1978; Brown and Lawson 1975). To these migrants, the difficulties likely to be encountered in urban centres are often overshadowed by the anticipated gains in freedom, safety, security and upward socioeconomic mobility.

Earlier migratory streams were selective in favour of men (Byerlee, 1974; Anarfi et al., 2003; GSS, 2005). In colonial and post-colonial Africa, particularly in Botswana, Lesotho and South Africa, men were mostly recruited into government agencies, railway corporations and mining companies (Gugler, 1989; GSS, 2005). The higher living costs and prototype accommodations provided for male workers often precluded wives from joining their husbands in the short term (Pirie and da Silva, 1986). For rural women, the loss of family and social networks, prestige and benefits associated with fulfilment of their biological functions, have in the past, constrained migration into cities.

While migrants are now increasingly relocating directly into mega-cities, the selectivity has become more complex. Unskilled rural women are increasingly daring to relocate on their own, unattached and unaccompanied. Thadani and Todaro (1979) and Gugler (1989) have all chronicled the growing preponderance of female migrants in cities. In sub-Saharan Africa, educated, young unmarried women had higher tendencies to migrate into cities than their male counterparts (Brockerhoff and Eu, 1993). In Latin American cities, migrants were predominantly young, female and unmarried (Brumer, 2008; Rengert, 1978 as cited in Khoo et al, 1984; Arias and Palloni, 1999; Whiteford, 1978) and were pursuing educational advancement as well as employment in domestic capacities, factories and as traders (Pei-Chia Lan, 2008; Sudarkasa, 1977).

Cultural conservatism in rural areas have also compelled women to migrate on their own. In traditional societies where girls and women are 
generally secluded as the case is among Hausas in Nigeria (Pittin, 1984) and Indian tribes in Columbia (Whiteford, 1978), out-migration could be a "liberating experience" from female servitude. In Brazil, younger rural females are typically excluded from inheriting family lands and their labour is not duly recognized (Brumer, 2008). In other Latin American countries, mechanized agriculture has essentially displaced female farm labour thus adding to the pressure to migrate into cities (Khoo et al, 1984). In rural China (Fan and Huang, 1998) as in parts of West Africa, women are considered as temporary family members and so receive less education than their male counterparts. Unlike the Chinese male who get access to higher education or opportunities for recruitment into the army, marriage to an urban resident is perceived as a gateway among females into cities (Fan and Huang, 1998). Deprived of local opportunities, many nurture chances of accessing urban socio-economic opportunities via migration in order to "....gain independence, respect and perhaps awareness that their condition is not fated....." (Morokvasic, 1984).

Women also migrate on their own due to unsustainably small landholdings (passed on more to sons rather than daughters), the death of a spouse and subsequent loss of land, forced marriages (sometimes into polygamous families) as well as physical and mental abuse perpetrated by their male counterparts and family members (Whiteford, 1978). For these individual females, while city-bound migration could be a harrowing experience, it may also provide new lifetime opportunities. This array of migration pressures means that many women arrive in the city not necessarily "pure and ...in stable unions" as asserted by Perlman (1987) but may be already physically and emotionally bruised. Unless there are established social networks, migrants secure footholds in informal settlements which are stereotypically regarded as dens for "armed robbers, prostitutes and drug pushers" and social misfits (Grant, 2006) and are therefore perceived as threats to neighbouring communities. Internally, the residents face insurmountable difficulties in terms of security and safety, lack of reliable social and personal space as well as access to basic services and infrastructure (Arias and Palloni, 1999). These "faceless" women are disconnected from their established traditional social networks which provided a rich source of financial and moral support in times of stress and illness and also helped resolve the conflicts between work and child care.

The creation of a squatter settlement in $\mathrm{Ku}$ masi

Kumasi has a long history of in-migration. Located along the erstwhile trans-Saharan trade route and functioning as the traditional seat of the now defunct Asante Empire, Kumasi has flourished and expanded since its foundation in the $18^{\text {th }}$ century. Due to its central location, major roads radiate from the city into other parts of the country and into neighbouring Burkina Faso and Cote D'Ivoire. Kumasi is also located on the apex of the now defunct triangular railway network. These transportation functions have made the city a major industrial and commercial centre and an ideal destination or transit for migrants. According to the GSS (2005), about $48.6 \%$ of the population was born outside the city. The city's population stood at 2,035,064 in 2010, thus representing an annual growth rate of about $5.7 \%$ between the 2000 and 2010 intercensal period (GSS, 2012).

Despite rapid in-migration, large-scale squatter settlements which characterize major cities of the developing world were not evident in $\mathrm{Ku}-$ masi as the traditional land tenure system provided limited opportunities for squatting (Peil, 1976; Konadu-Agyeman, 1990). Long distance migrants were typically allocated lands on the peripheries of settlements to build their communities. Inner city suburbs including Akwatia Line and Asawase absorbed a large stream of long distance migrants. On the other hand, migrants from neighbouring Asante settlements were typically accommodated in multi-storey "compound houses", in Asafo, Amakom, Ban- 


\section{Owusu-Ansah and Addai}

tama, Ashanti New Town and other Asante suburbs.

Table 1 suggests that some inner suburbs were unable to accommodate the unending streams of migrants and actually experienced negative growth rates during the 1984-2000 intercensal period. This trend is mainly attributable to unregulated conversions and remodelling of residential structures for commercial use hence displacing the original residents and limiting opportunities for new arrivals. While migrants are being priced out of inner cities, urban fringe lands are typically sold to the urban middle class and Ghanaian expatriates who construct houses for predominantly single-households (Owusu-Ansah and O'Connor, 2010). The combination of these growth pressures created the right conditions for the first large-scale squatter settlement of its kind in the city.

The squatter settlement is located on a 100 acre land leased during the colonial era for the $\mathrm{Ku}$ masi Race Course. Although conveniently loc- ated in close proximity to the central business district at Adum and the Kumasi Central Market as shown in Fig. 1, the site has major drawbacks. First, it is located on the headwaters of the Subin River, hence, susceptible to flooding. Secondly, it is located within a network of major institutions, including the National Zoological Garden (Kumasi Zoo), Ghana National Cultural Centre, Asanteman Senior High School, St. Louis Training College, several churches, an FM Radio station and a cluster of primary schools which all require serene atmospheres to operate in contrast to the cacophony of noise generated during day and night by the settlers. The site shown in Fig. 2 is characterized by spatial disarray of temporary structures used for housing and are intermixed with structures used for businesses (such as corn mills and restaurants) and for petty trading.

The re-use of the defunct Race Course by the settlers can be traced back to 1992 when longdistance vehicles (plying the northern parts of the country), along with the traders were relo-

Table 1: Population distribution and annual growth rates in inner city suburbs

\begin{tabular}{cccccc}
\hline & \multicolumn{3}{c}{ Population } & \multicolumn{2}{c}{ Growth rates } \\
\hline Inner city suburbs & $\mathbf{1 9 7 0}$ & $\mathbf{1 9 8 4}$ & $\mathbf{2 , 0 0 0}$ & $\mathbf{1 9 7 0 - 1 9 8 4}$ & $\mathbf{1 9 8 4 - 2 0 0 0}$ \\
Adum & 12,991 & 9,693 & 8,016 & -2.1 & -1.2 \\
Asafo & 7,689 & 20,375 & 18,457 & 7.2 & -0.6 \\
Ashanti New Town & 1,269 & 4,071 & 3,337 & 8.7 & -1.2 \\
$\quad$ (Mbrom) & & & & & -0.5 \\
Ashanti New Town & 18,667 & 21,596 & 20,031 & 1.0 & \\
$\quad$ (Odumasi) & & & & & 1.4 \\
North Suntreso & 5,373 & 8,066 & 10,127 & 2.9 & 1.5 \\
Asawase/Zongos & 8,097 & 36,429 & 46,243 & 11.3 & 2.4 \\
$\quad$ Amakom & 14,787 & 26,582 & 39,060 & 4.3 & 2.4 \\
$\quad$ Bantama & 12,666 & 14,984 & 22,060 & 1.2 & 4.0 \\
Fanti New Town & 4,197 & 6,668 & 12,407 & 3.4 & 7.4 \\
$\quad$ Asokwa & 700 & 8,123 & 18,747 & 19.1 & \\
Ashanti New Town & 1,754 & 7,600 & 24,458 & 11.0 & 7.7 \\
(Manhyia/Krobo) & & & & & \\
Pampaso & 634 & 901 & 2,966 & 2.5 & \\
\hline
\end{tabular}

Source: Ghana Statistical Service, 2005 
Life in a squatter settlement ... 77

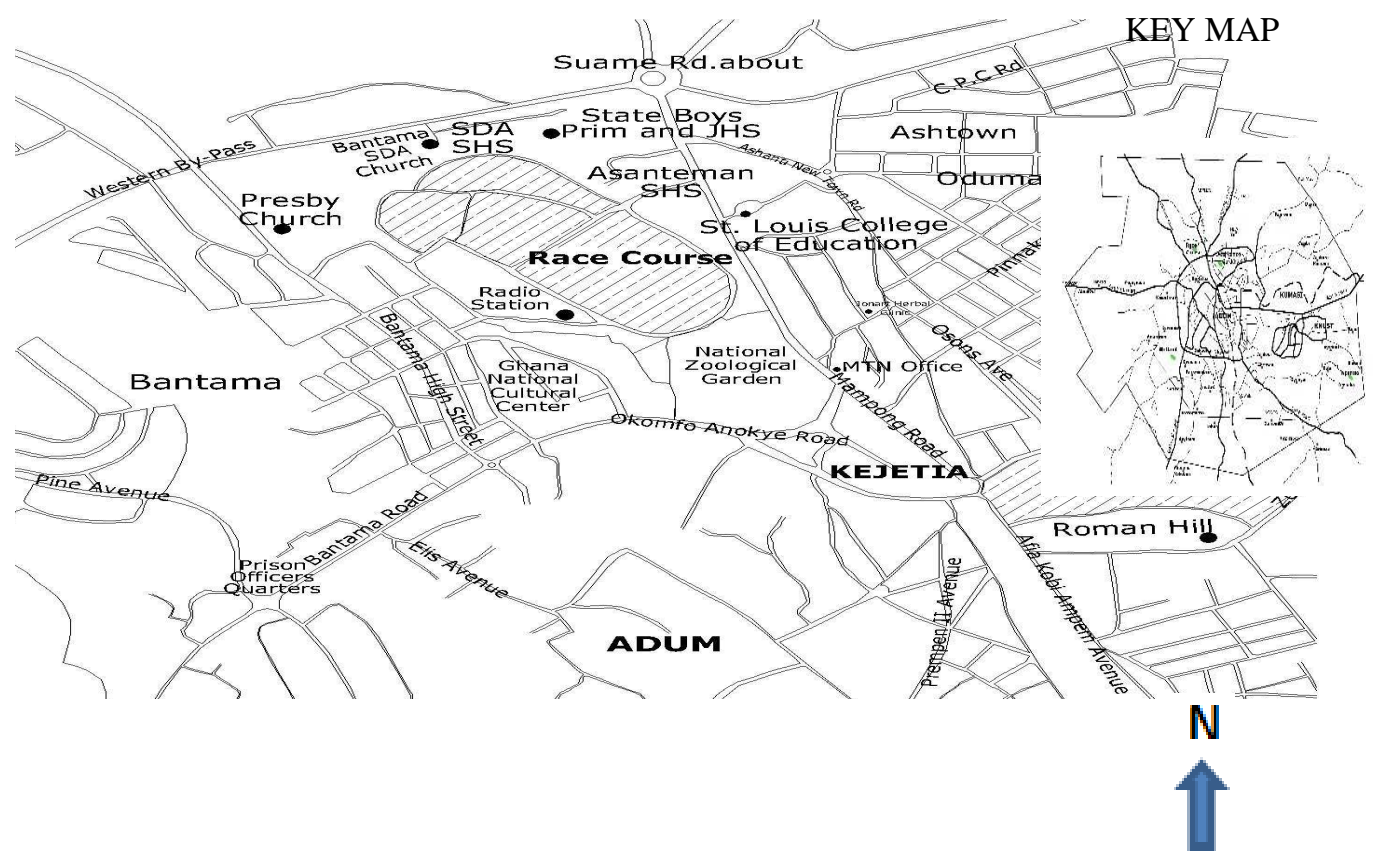

Fig. 1: Parts of Kumasi showing the Race Course north of Adum (CBD (Adapted from Google Earth)

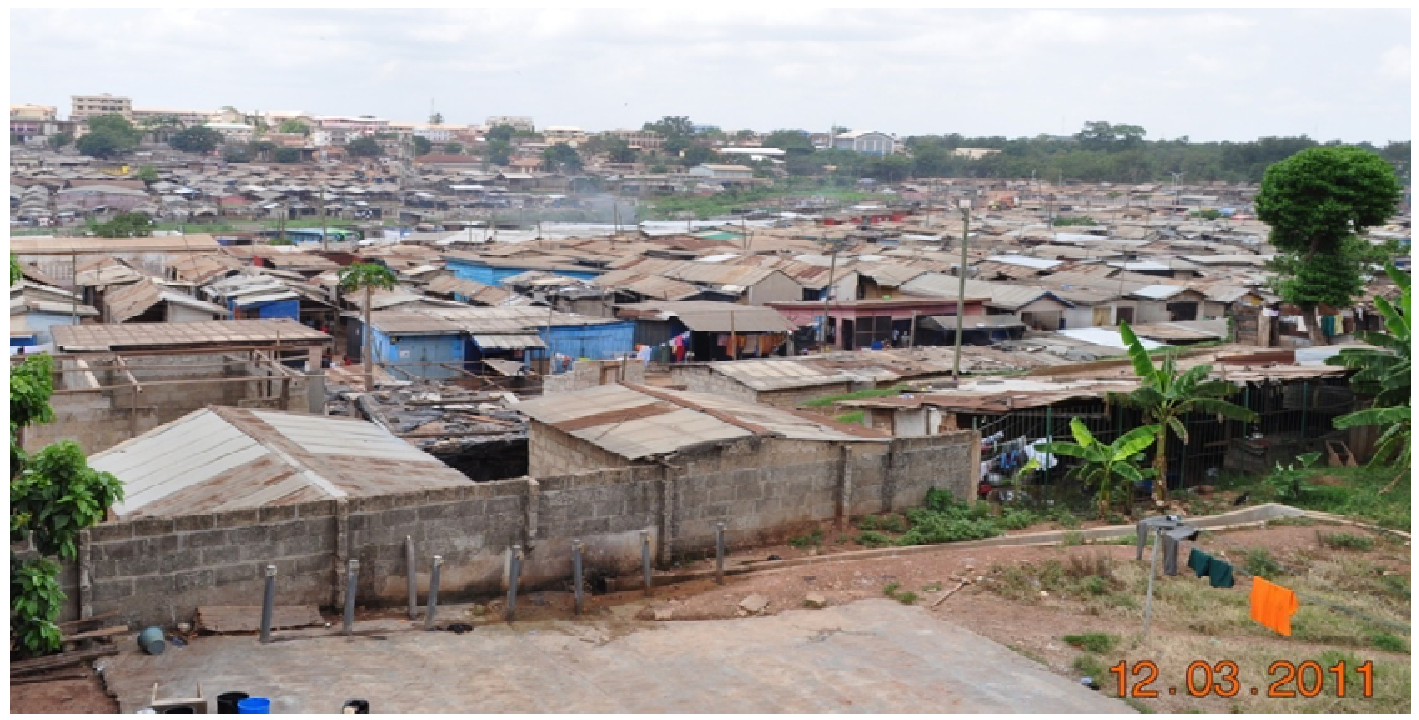

Fig. 2: A view of the squatter settlement from the wall of Asanteman Senior High School Source: Author's Photo 


\section{Owusu-Ansah and Addai}

cated "temporarily" from the Kajetia lorry terminal to the site. This was to make way for the reconstruction of the Kajetia terminal. Soon, some of the migrants arriving from northern Ghana erected temporary shelters on vacant lands around the relocated lorry terminal. The government extended water and electricity to the growing squatter settlement. However, following a change of leadership in the year 2000, the new Kumasi mayor halted all upgrades and service provision for fear of providing de facto land security to the settlers. The population grew rapidly from 867 in the year 2000 to 1761 in 2010 (Table 2) with females out-numbering the male population hence providing a special research opportunity.

\section{METHODOLOGY}

A preliminary investigation was conducted to identify groups that could facilitate the data collection. A sketch map of the settlement based on access roads showed five main housing clusters with similar characteristics. A rough count in the two randomly selected clusters yielded around 300 structures. The survey included all females in every second structure, counting from the structure at the main road intersection. This survey also showed that nearly half of these structures were empty during the morning as they were only utilized for resting, cooking and sleeping. The main survey was therefore conducted during the afternoon and evening when the residents returned to their homes.

Table 2: Population growth at Race Course

\begin{tabular}{cccl}
\hline & 2000 & $\mathbf{2 0 1 0}$ & $\begin{array}{l}\text { Growth } \\
\text { Rates }\end{array}$ \\
\hline Male & 367 & 715 & 6.9 \\
Female & 500 & 1046 & 7.7 \\
Total & 867 & 1761 & 7.3 \\
\hline
\end{tabular}

Source: KMA, 2010
A pre-test on a sample of 20 respondents produced fairly similar responses; therefore the overall ambition of reaching 150 females was scaled back to 100 . The survey was administered in the first week of March 2011. The structures were visited a number of times to ensure that 50 respondents were surveyed in each of the two selected clusters. With the assistance of a male student who lived in the settlement, the team overcame the high level of suspicion about the utilization of the data. It was rumoured that at the time that, under the auspices of the Asantehene (King of Ashanti), the area was going to be redeveloped into a hospitality complex. The Department of Environmental Health, Domestic Violence and Victim Support Unit and The Daughters of the Blessed Trinity (a non-governmental organization) were also consulted to clarify some of issues emerging from the survey. However, these consultations yielded little additional information about the squatters.

\section{Women in the Kumasi Race Course Squatter Settlement}

This section analyses the origin, socioeconomic characteristics, education, reproductive health, family life (child upbringing), and safety and security concerns of women which subsequently formed the basis for the recommendations.

\section{Places of origin of the migrants}

Fig. 3 suggests that nearly $50 \%$ of the sampled population was from one particular ethnic group, the Frafras, who originate from the Upper East Region of Ghana. The Ghana Statistical Service (2003) revealed that the region was one of the most deprived in Ghana, with female literacy rates of $20.3 \%$ falling well below that of their male counterparts $(30.9 \%)$. The Frafras have had a long history of southwards migration (particularly during the long-dry season and inactive period in local agriculture) and were studied in Accra by Hart (1973). That concentration suggests that there were well established connections from the Race Course site that reach back to the Upper East Regions. 
Life in a squatter settlement ... 79

The respondents regularly relied on a supportive local network of family members and friends. However, migrants from two other regions of northern Ghana (Upper West and Northern Region) were insignificant. The results showed that all the regions were fairly represented except the Central and Eastern regions. It is possible that migrants from these re- gion had existing networks elsewhere in the city, or even in the other parts of the squatter settlement which were not studied. It was surprising to find that $20 \%$ of the respondents came from settlements within the Ashanti Region. In the past such migrants would be accommodated with families in indigenous Asante suburbs. The fact that a significant share

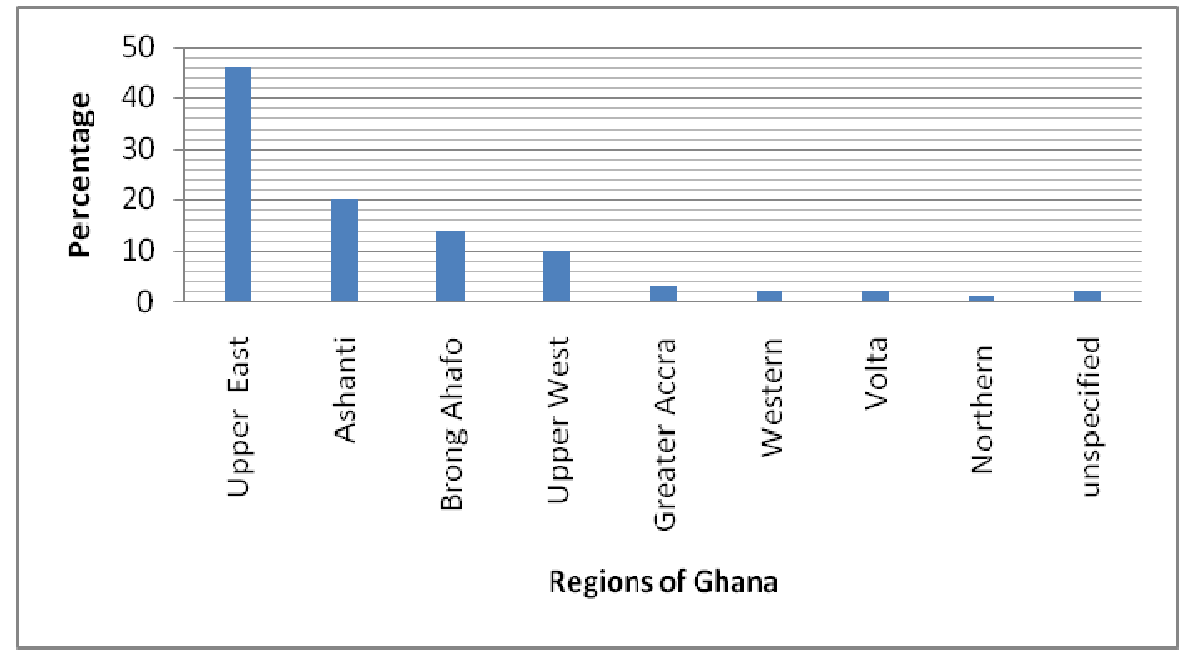

Fig. 3: Places of origin of the respondents

Source: Field Survey, 2011

Table 3: Ages of respondents and their motives for migration

\begin{tabular}{lcccccc}
\hline \multicolumn{1}{c}{ Ages } & $\mathbf{1 1 - 2 0}$ & $\mathbf{2 1 - 3 0}$ & $\mathbf{3 1 - 4 0}$ & $\mathbf{4 1 - 5 0}$ & $\mathbf{4 1 - 5 1}$ & Total \\
\hline Motivation & No $(\%)$ & No $(\%)$ & No $(\%)$ & No $(\%)$ & No $(\%)$ & No $(\%)$ \\
Family reunion & 1 & 7 & 2 & 2 & & 12 \\
Escaping from cultural practices & 5 & 6 & & & & 11 \\
Poverty & 6 & 18 & 2 & 1 & 1 & 28 \\
Seeking jobs & 16 & 21 & 2 & 2 & 1 & 42 \\
Others & 4 & 3 & & & & 7 \\
Total & $\mathbf{3 2}$ & $\mathbf{5 5}$ & $\mathbf{6}$ & $\mathbf{5}$ & $\mathbf{2}$ & $\mathbf{1 0 0}$ \\
\hline
\end{tabular}

Source: Field Survey, 2011 
was in the settlement shows how much housing and infrastructural conditions in these suburbs have now come under pressure, and that such migrants are increasingly solving their housing needs in this settlement just as their counterparts from the other regions.

Ages and motives of respondents

Table 3 shows that the dominant population group was those aged 21-30 followed by the 11 -20 age cohort. This youthful nature of the population suggests that they may not have significant attachments to their homes of origin. The results suggest that the quest for upward socio-economic mobility was the key motivation to migrate. A substantial proportion of the migrants $(28 \%)$ migrated to escape poverty in their places of origin while $42 \%$ were motivated by perceived job opportunities in the city. Other reasons such as early and forced marriages, polygamous relationships and the trailing wife effect often cited in literature did not emerge as major reasons for out-migration.

\section{Knowledge of opportunities available}

The research found that nearly all the respondents had prior knowledge of the activities and opportunities available within the settlement thus confirming the idea that city-bound migrants were not unaware of the conditions in heir potential destinations (Okpara, 1998; Sluzki, 1993; Whiteford, 1978). For example, in order to start work soon after arrival, about $50 \%$ of the head porters either brought their own head pans or purchased their first head pans upon arrival with money they brought from their home villages.

\section{Length of stay}

Fig. 4 shows that a substantial proportion of the respondents (58\%) arrived during the last two years, and that only eight percent had lived in the settlement for more than ten years. This suggests that the settlement was mostly used as a transit camp until alternative accommodation was found somewhere in the city or until they returned to their home regions. Surprisingly, nearly $65 \%$ of respondents had no immediate plans to relocate into other suburbs even after expressing high levels of personal insecurity and the possibility of forced removal. This implied that alternative housing opportunities elsewhere were limited. The survey showed, despite their youthful nature, many residents

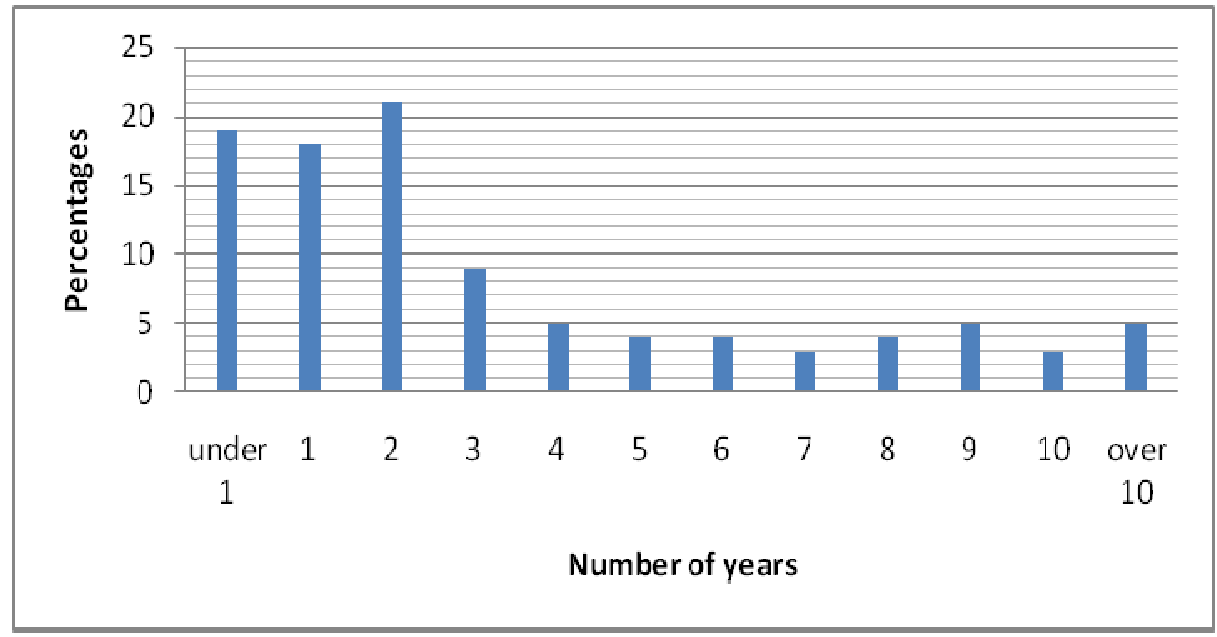

Fig. 4: Length of stay among respondents

Source: Field Survey, 2011

Journal of Science and Technology @ KNUST December 2013 
Life in a squatter settlement ... 81

shuttled back and forth between the city and their home villages at least once every three months to reunite with their families and participate in some local activities.

\section{Educational status}

The migrants were mostly uneducated and unskilled. Table 4 shows that $44 \%$ had never been to school and only nine percent had attained senior high school education. A host of factors including lack of funds, cultural preference to educate boys as opposed to girls, the inability to cope with academic life, the glamour of the city and the push by relatives and friends seemed to have combined to curtail their educational advancement. However, many younger respondents expressed their desire to return to their home origins to continue their education after a brief sojourn in Kumasi. They argued that they could not afford the school fees in Kumasi. Recognizing the importance of education in socio-economic transformation, five respondents had enrolled their children in the nearby State Boys Primary and Junior Secondary Schools.

However, the respondents worked on daily basis from dawn to dusk hence admittedly could not effectively monitor the progress of their wards. With the emphasis on survival strategies, it is likely that the children's education may suffer and are likely to drop out, just like many of their parents. However, six respondents had sent their children to their homes of origin to live with their parents for proper monitoring. Here too, they lose the opportunity to monitor the development of their children in their formative years.

\section{Income generating activities}

With their limited educational background, the respondents had no illusions of obtaining jobs in the formal sector. The job categorizations shown in Fig. 5 must be interpreted with caution as they regularly switched from one activity to the other whenever presented with opportunities. Even the $8 \%$ of the respondents identified as apprentices similarly engaged in other kinds of activities whenever the need arose.

The most difficult but probably the most rewarding occupation was the head porting known locally as kayayees. A number of research on this group has been carried out (see Oberhauser and Yeboah, 2012; Van den Berg, 2007; Baah-Ennumh et al., 2012). The porters begun work at dawn when vehicles delivered foodstuffs from the hinterlands into the market. Demand was particularly high during this time as customers and traders purchased their wares in bulk and therefore require their services. The need for survival has accelerated the competition between female head porters and male truck pushers as the latter could carry larger and heavier loads. The female typically charged an average of GHC0.50 (30 US cents) for headloads and would ask for an increase if the distance appeared longer than they had antici-

Table 4: Level of education of respondents

\begin{tabular}{ccccccc}
\hline & $11-20$ & $21-30$ & $31-40$ & $41-50$ & $41-51$ & Total $(\%)$ \\
\hline Primary & 4 & 6 & & & & 10 \\
Junior high & 13 & 22 & 1 & 1 & & 37 \\
Senior High & 5 & 3 & 1 & & & 9 \\
Never & 10 & 24 & 4 & 4 & 2 & 44 \\
Total & $\mathbf{3 2}$ & $\mathbf{5 5}$ & $\mathbf{6}$ & $\mathbf{5}$ & $\mathbf{2}$ & $\mathbf{1 0 0}$ \\
\hline
\end{tabular}

Source: Authors' Survey (2011) 


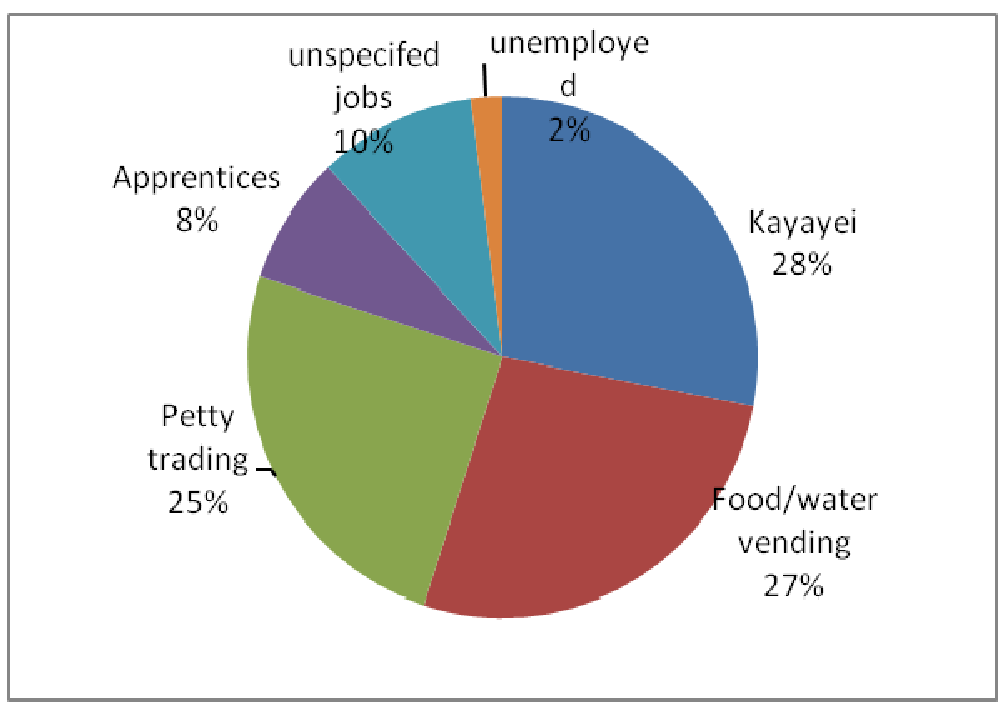

Fig. 5: Economic activities identified in the settlement

Source: Field Survey, 2011

pated. The nursing mothers worked with their babies tied on their backs hence the conflict between work and childcare becomes a daily struggle. They were regularly bypassed for the services of women without children on their backs and so limiting the job opportunities of those who probably needed them the most. The head porters rested or cooked in the afternoons in groups as a means of social protection, enjoyed gossips and then moved to nearby markets, the CBD or the Central Market to continue their operations in the late afternoon.

About $27 \%$ of those surveyed sold foodstuffs and/or water on the wayside or in restaurants (popularly called "chop bars") or roamed in the market and in the CBD to exhibit their wares. The petty traders $(25 \%)$ who displayed their wares on table tops or in other wooden structures tended to be older, more established and economically better off than the rest. Many traders had mobilized savings from earlier activities either as head porters or borrowed money from families and friends to engage in petty trading activities. The lack of collateral security precluded them from accessing loans from banks or even micro-finance agencies, and so constrained their housing choice to the settlement.

With respect to incomes, $73 \%$ of the respondents reported daily gross earnings of about GHC5 or less (US3.20) which was more than the Ghanaian minimum daily wage of GHC3.70 in 2011. About 4\% earned more than GHC30.00 a day, nearly three times that of a waged labourer in the construction industry. Nearly all the respondents indicated that they regularly remitted money to their families not only because they felt money would be stolen from them in Kumasi but also because these remittances were sometimes their families' lifelines. Despite their precarious employment opportunities, they paid their daily market tolls, housing rent, access to toilet facilities and water and still could save money and remit money to their relatives. This shows that the migrants contribute to national socio-economic progress, 
Life in a squatter settlement ... 83

a view similarly expressed by Ulack (1978) in his study of similar residents in the Philippines.

\section{Shelter and environmental conditions}

Despite the fact that the settlement had existed for at least ten years, the structures were overwhelmingly made of plastic, zinc and wood and were mostly constructed without concrete base despite the fact that the area was often soggy. The rooms were rented from pioneering male settlers. They regularly complained of bedbugs, ants, mosquitoes and even snakes. Leaking roofs were typically covered with plastic sheeting hence making the rooms unbearably hot during the day and night. Their "transient" nature appears to have constrained the formation of ethnic associations and self-help organizations. The hype about "squatters take pride", sense of belongingness, self-help and consolidation in anticipation of future regularization as found in the Philippines and in Kuala Lumpur (Ulack, 1978) were not obvious in this settlement. The overall impression was that the owners felt insecure in investing in an area they had occupied illegally.

The traders who tended to be older and more established, rented individual rooms while the younger unattached women tended to rent and stay in groups ranging from six to ten. The structures ranged from $2 \times 3$ meters to $6 \times 6$ meters in size with the larger ones typically being rented on group basis. There was hardly enough room for all the individual members; members who came late had to sleep outside the door thus becoming vulnerable to attack by sexual predators. The monthly rent ranged from GHC 5-15 (equivalent to US\$3 to US\$8) depending on the size, the rental arrangement and the structural conditions. Some respondents conceded that they were often coerced to exchange sex for the monthly rent especially when they were unable to pay it on time. In all, about $11 \%$ claimed to have been attacked either in the night when they stepped outside to use the bathroom or at dawn when they set out to work. About 9\% claimed to be living with their boyfriends and $11 \%$ slept in the structures used for hairdressing, food production, corn milling and welding shops. In this manner, they acted as the de facto "night watchmen" which actually amounted to rent payments to the owners.

Access to electricity, water and sanitation infrastructure

Most structures in the settlement were supplied with electricity mostly illegally connected. A bucket of water cost about 20 to 30 pesewas. Elsewhere in the city a bucket of water cost between 10 and 20 pesewas. While they cherished water availability, they also regularly complained about the "high" costs especially when many buckets were required for domestic purposes. This obviously reinforces the idea that the poor tend to pay more for water supply, a service which typically receives government subsidy.

Most structures lacked bathrooms and toilet facilities and so the residents used the three public toilet facilities and two bathrooms available in the two clusters. One of the toilet facilities which was regularly maintained was used at a fee of 20 pesewas per visit. The other two toilets appeared to have been abandoned and so were used for free. They complained that it was impossible to navigate one's way inside those toilets thus compelling some to defecate around the facilities or around the Subin stream. A young woman remarked that "every time I visit the toilet facility my body stinks badly so I have to bath and this cost extra pesewas of my income. I often get candidiasis too so I have decided to do it in the bush.' Those who feared being attacked wrapped up their faeces in polythene bags and threw them out in the night. The Subin stream was highly polluted with solid and faecal matter thus raising some health concerns. While the public toilets had separate sections for male and female, the three public bathrooms were patronized by both sexes thus raising concerns about privacy, security, and gender-based violence particularly during the night. The women coped with this challenge by bathing in groups before nightfall. 
Family life

The overwhelming proportion of respondents 70 was unmarried (Table 5). This independence clearly contributes to migration into urban centres, a fact which has been regularly pointed out in migration literature. Out of that figure, 31 respondents had children but were unmarried while five respondents were pregnant but unmarried. This calls for the need for family planning services in the area. Perhaps due to the anticipated conditions, the women who had children before relocating here arrived only with the youngest child while the rest were left in the care of other family members.

Nearly a third of all the unmarried women who lived with their boyfriends remarked that they would be better off living on their own due to the frequent physical, verbal and emotional abuses allegedly perpetrated by their male counterparts. A young unmarried woman recounted that her boyfriend regularly brought women into the shelter. When confronted, she was beaten and thrown out along with her twoyear old baby. Unfortunately, there were no mechanisms for redress of such grievances.

\section{Health, safety and security}

The soggy and unclean environment provided fertile grounds for the breeding of mosquitoes. Though reporting frequent illnesses particularly malaria, only $34 \%$ attended hospitals. None of them had enrolled in the National Health Insurance Scheme as they claimed the contributions (premium) were unaffordable and/or that they lacked the time to join queues at the offices.
Again, despite the availability of "free" delivery programme at health centres in Ghana, five respondents delivered in the settlement with support from local birth attendants. They reported that the items required for the delivery process in the hospitals were unaffordable.

While generally, security is problematic in squatter settlements, the prevailing conditions are worse for the young and unattached women due to potential attacks by their male counterparts. Absence of streetlights and police presence all combine to exacerbate their vulnerabilities and risks to attacks and rapes. The settlement reported at least one major fire outbreak each year. While some respondents attributed these outbreaks to illegal electricity connections and the use of charcoal and wood for fire in such crowded environments, others speculated that the fires were deliberately started by arsonists to create opportunities for looting.

In most cases, the settlers were treated as if they did not exist. The official rhetoric to promote the needs of vulnerable women and children is not backed by action and that the Ministry of Gender, Children and Social Protection had no specific programme for these settlers. Similarly, the Domestic Violence and Victim Support Unit which is a specialized unit within the Ghana Police Service responsible for addressing abuses and violence against women indicated that psychological and physical abuse cases were rarely reported. The respondents regularly mentioned that they did not trust the

Table 5: Marital status of respondents

\begin{tabular}{lccc}
\hline & Married & Unmarried & Total \\
\hline With children & 28 & 31 & 59 \\
Without children & 1 & 34 & 35 \\
Pregnant & 1 & 5 & 6 \\
Total & $\mathbf{3 0}$ & $\mathbf{7 0}$ & $\mathbf{1 0 0}$ \\
\hline
\end{tabular}

Source: Field Survey, 2011 
police to bring the perpetrators to justice. The Environmental Health Department (charged with the responsibility for monitoring environmental sanitation and housing conditions) rarely visited the settlement. The Department has probably bought into the myth that attitudes among squatters were hard to change and that environmental challenges were intractable and so had written off this community.

\section{Skills training}

The research found that there were no official training programmes to provide long-term economic sustenance for the settlers. This vacuum was filled by a faith-based non-governmental organization called The Daughters of the Blessed Trinity which regularly trained some of the young women in dressmaking, baking and other activities with the intention of resettling them back in their homes of origin. However, according to the nuns, the beneficiaries would accept the package and return home only to come back into the settlement after some time. This shows attempts to return these women to their homes of origin may be counterproductive. As Dumont and Spielvogel (2007) rightly emphasized, "...some will return home and others will not; some will move on to a new destination, while others will be caught up in a cycle of circular migration". This research showed that the overwhelming proportion did not have plans to return home permanently in the short-term. They were determined to eke a living despite all the environmental and health and safety hazards. Therefore skill training should be geared towards their eventual integration in the city rather than used as a bait to return to their places of origin.

\section{CONCLUSIONS AND POLICY RECOM- MENDATIONS}

The research has shown that the female migrants contribute towards the evolution of squatter settlements through their numbers, their length of stay and their work. They are predominantly young and expressed no desire to return to their homes of origin in the short term. They had not yet "succeeded" in transf- orming their socio-economic status to merit a grand return with the so-called "innovatory spirit” (King, 1978).

Given that resources are polarized in the few major centres, rural-to-urban migration is likely to continue. Therefore the larger Ghanaian cities must develop better strategies to manage the process and its outcomes with particular attention to addressing the special needs of migrant women who constitute a substantial proportion of the migratory flows. Recognizing that the squatter settlement exists and that it plays a part in the functioning of the city is critical for policy response. Despite the distinct population and unique needs, their numbers were simply added to that of Bantama thus depriving the respondents of effective representation at the Metropolitan level. Given the fact that these women were likely to shy away from government offices, direct visits by the city officials to the settlement are critical in encouraging them to access the opportunities in health and education and so reduce their vulnerabilities. The government should extend social and community services such as health post and educational facilities (even if temporary) as well as skill training in alternative livelihoods.

A longer term policy to promote their socioeconomic and spatial integration is by providing commercial space and alternative housing for the newly arrived migrant. This calls for a rethink of the tenets of the traditional land tenure system and housing policy in order to promote varying housing types. In this light, the city authorities could liaise with traditional leaders for land to be provided to private sector developers for the construction of apartments or hostels that are specifically geared to the needs of recent migrants. Similarly, developers of inner city lands should be mandated by the $\mathrm{Ku}$ masi Planning Committee to include varying housing types in new high rise buildings as a condition for approval. In the case of Kumasi, as outlined in the postscript, the policy desire to limit the development of squatter settlement has been applied in a drastic way. 


\section{Owusu-Ansah and Addai}

Rather than addressing the needs of the residents, and perhaps improving the environmental conditions, the settlement was considered as "out of place" and was demolished in September 2011, not long after this research was carried out. The Asantehene who holds ultimate allodial interest in the land is said to have leased the land for the development of a hospitality complex. A large number of the previous residents are understood to have occupied uncompleted and apparently abandoned government buildings while others have formed pockets of squatter settlements around the $\mathrm{Ku}$ masi Technical Institute and along the railway line. Recent police raids have reinforced the general perception that these new abodes are controlled by criminal elements thus increasing the vulnerabilities of the female migrants. Addressing some of the rural-urban imbalance and following up the residential moves of the settlers could provide an important step in understanding the development of migrant squatter settlements.

\section{REFERENCES}

Arias, E. and Palloni, A. (1999). Prevalence and Patterns of Female Headed Households in Latin America: 1970-1990. Journal of Comparative Family Studies, 30 (2): 257279

Anarfi J. K., Ababio, O. M. and Tiemoko, R. (2003). Migration from and to Ghana: A Background Paper. The Development Research Centre on Migration, Globalisation and Poverty, University of Sussex, Brighton. Accessed on $1^{\text {st }}$ May, 2013 at www.migrationdrc.org

Baah-Ennumh, T. Y., Amponsah, O. and Owusu Adoma, M. (2012) The Living Conditions of Female Head Porters in the $\mathrm{Ku}$ masi Metropolis, Ghana. Journal of Social and Development Sciences, 3 (7): 229-244

Byerlee, D. (1974). Rural-Urban Migration in Africa: Theory, Policy and Research Implications. International Migration Review,
8(4):543-566.

Brockerhoff, M. and Eu, H. (1993). Demographic and Socioeconomic Determinants of Female Rural to Urban Migration in SubSaharan Africa. International Migration Review, 27(3): 557-577

Brown, L. A., and Lawson, V. A. (1985). Migration in Third World Settings, Uneven Development, and Conventional Modeling: A Case Study of Costa Rica. Annals of the Association of American Geographers, 75(1): 29-47

Brumer, A. (2008). Gender Relations in Family -Farm Agriculture and Rural-Urban Migration in Brazil. Latin American Perspectives, 35(6): 11-28

Cadwell, J. C (1968). Determinants of RuralUrban Migration in Ghana. Population Studies, 22(3): 361-377

Cooke T. J. and Bailey, A. J (1996). Family Migration and the Employment of Married Women and Men. Economic Geography, 72 (1): $38-48$

Dumont, J.C. and Spielvogel, G. (2007). Return Migration: A New Perspective. International Migration Outlook, 2008 Edition. OECD.

Kees van der Geest (2010). Local Perceptions of Migration From North West Ghana. Africa, 80: 595-619

King, R. (1978). Return Migration: A Neglected Aspect of Population Geography. Area, 10(3): 175-182

Fan, C., and Huang, Y. (1998) Waves of Rural Brides: Female Marriage Migration in China: Annals of the Association of American Geographers, 88(2): 227-251

Ghana Statistical Service (2012). 2010 Population and Housing Census. Government of 
Ghana, Accra.

Ghana Statistical Service (2005). Analytical Report Volume 2, Population and Housing Census Government of Ghana, Accra.

Ghana Statistical Service (2003) Core Welfare Indicators Questionnaire Survey, Flyer No. 21 Upper West Region Summary, Government of Ghana, Accra. Accessed on March 21, 2013 at: www.statsghana.gov.gh/docfiles/ cwiq\%20\%20upp_-_west_-_reg.pdf

Grant, R. (2006). Out of Place? Global Citizens in Local Spaces: A Study of the Informal Settlements in the Korle Lagoon Environs in Accra, Ghana Urban Forum, 17(1):1-24

Gugler, J. (1989). Women Stay on the Farm No More: Changing Patterns of Rural-Urban Migration in Sub-Saharan Africa. The Journal of Modern African Studies, 27 (2): 347352

Hart, K. (1973) Informal income opportunities and urban employment in Ghana. The Journal of Modern African Studies, 11(1): 61-89

Hear V. N, Bakewell, O and Long, K. (2012). Drivers of Migration, Migrating out of Poverty, Research Programme Consortium, Working Paper 1, University of Oxford

Khoo, S. E., Smith, P. C. and Fawcett, J. T. (1984). Migration of Women to Cities: The Asian Situation in Comparative Perspective, International Migration Review, Special Issue: Women in Migration. 18(4): 1247-1263

Konadu-Agyemang, K. O. (1991). Reflections on the Absence of Squatter Settlements in West African Cities: The Case of Kumasi, Ghana. Urban Studies 28(1): 139-151

Morokvasic, M. (1984). Birds of Passage are also Women. Special Issue: Women in Migration, International Migration Review, 18 (4): $886-907$
Oberhauser, A. M. and Yeboah, M. A. (2012). Heavy burdens: Gendered livelihood strategies of porters in Accra, Ghana. Singapore Journal of Tropical Geography, 32 : 22-37

Okpara E. E. (1986). Rural-Urban Migration and Urban Employment Opportunities in Nigeria, Transactions of the Institute of British Geographers, 11 (1):67-74

Owusu-Ansah, J. K. and O'Connor, K. B. (2010). Housing demand in the urban fringe around Kumasi, Ghana. Journal of Housing and Built Environment. 25: 1-17.

Pei-Chia, L. (2008). Migrant Women's Bodies as Boundary Markers: Reproductive Crisis and Sexual Control in the Ethnic Frontiers of Taiwan. Signs, 33(4): 833-861

Peil, M. (1976). African Squatter Settlements: A Comparative Study. Urban Studies, 13: 155-156.

Perlman, J. E. (1987). Misconceptions of the urban poor and the dynamics of housing policy evolution. Journal of Planning Education and Research 6:187-196.

Pirie, G. H. and da Silva, M. (1986). Hostels for African Migrants in Greater Johannesburg. GeoJournal, 12(2): 173-180

Pittin, R. (1984). Migration of Women in Nigeria: The Hausa Case. International Migration Review, 18(4): 1293-131

Sluzki, C. E. (1979). Migration and Family Conflict. Family Process, 18(4):379-390

Sudarkasa, N (1977). Women and Migration in Contemporary West Africa. Signs, 3(1): 178189

Thadani, V. N. and Todaro, M. P. (1979). Female Migration in Developing Countries: A Framework for Analysis, Center for Policy Analysis Working Papers, Population Coun- 
York. Accessed on January 23, 2014 at http:// pdf.usaid.gov/pdf_docs/PNAAH327

United Nations Human Settlements Programme (2003). The Challenge of Slums: Global Report on Human Settlements, Kenya, Nairobi. Accessed on $3^{\text {rd }}$ March 2011 at www.unhabitat.org

Ulack, R. (1978). The Role of Urban Squatter Settlements. Annals of the Association of American Geographers, 68(4): 535-550

Van der Geest, K. (2010). Local Perceptions of Migration. From North West Ghana. Africa.
80(4): 595-619.

Van den Berg, Christa (2007). The Kayayei: survival in the city of Accra; Social capital and vulnerability in the lives of female head porters in Accra, Ghana. Unpublished Master's Thesis submitted to the International Development Studies, International School for Humanities and Social Sciences, University of Amsterdam

Whiteford, M. B. (1978). Women, Migration and Social Change: A Colombian Case Study. International Migration Review, 12 (2): $236-247$ 